\title{
MEDIAL EPICONDYLECTOMY OR ULNAR-NERVE TRANSPOSITION FOR ULNAR NEUROPATHY AT THE ELBOW?
}

\author{
G. G. GEUTJENS, R. J. LANGSTAFF, N. J. SMITH, \\ D. JEFFERSON, C. J. HOWELL, N. J. BARTON \\ From Queen's Medical Centre, Nottingham, England
}

W e carried out a prospective randomised study comparing medial epicondylectomy with anterior transposition for the treatment of ulnar neuropathy at the elbow. The mean follow-up period was 4.5 years and we assessed the patients neurologically and orthopaedically.

Neither procedure appeared to have a significant effect on elbow function. Our study showed better results after medial epicondylectomy; in particular patient satisfaction was higher than after ulnar nerve transposition. There were no significant differences in motor power or nerve-conduction rates and sensory fibres appeared to be more vulnerable to devascularisation.

J Bone Joint Surg [Br] 1996;78-B:777-9.

Received 15 August 1995; Accepted after revision 6 February 1996

The place of surgery in the treatment of lesions of the ulnar nerve at the elbow is uncertain: a variety of procedures has been recommended. There have been several reports of good results for medial epicondylectomy (King and Morgan 1959; Craven and Green 1980; Froimson and Zahwari 1980; Robinson, Aghasi and Halperin 1992), but none of these includes comparison with other operations, such as the commonly performed anterior transposition of the nerve (Macnicol 1979; Adelaar, Foster and McDowell 1984; Lundborg 1992).

G. G. Geutjens, FRCS, Senior Orthopaedic Registrar

N. J. Smith, MRCP, Consultant Neurophysiologist

D. Jefferson, MRCP, Consultant Neurologist

C. J. Howell, FRCS, Consultant Orthopaedic Surgeon

N. J. Barton, FRCS, Consultant Hand Surgeon

University Hospital, Queen's Medical Centre, Nottingham NG7 2UH, UK.

R. J. Langstaff, FRCS, Consultant Orthopaedic Surgeon Hillingdon Hospital, Hillingdon, Uxbridge, Middlesex UB8 3NN, UK.

Correspondence should be sent to Mr G. G. Geutjens at Flat 3, 19 Newcastle Drive, The Park, Nottingham NG7 1AA, UK.

(C)1996 British Editorial Society of Bone and Joint Surgery 0301-620X/96/51220\$2.00
We have performed a prospective randomised study of medial epicondylectomy and anterior transposition for the treatment of lesions of the ulnar nerve at the elbow.

\section{PATIENTS AND METHODS}

From 1985 to 1992, a total of 52 patients had operations for ulnar neuropathy and were entered into the study. Nine were lost to follow-up of whom two had died, records were untraceable in four, and three had moved away and could not be contacted. This left 43 patients, four of whom had bilateral operations, giving 47 cases. The mean age at operation was 58 years ( 36 to 85 ). Seven patients had preexisting osteoarthritis of the elbow, but there was no apparent cause in 36 . For entry into the study, patients had to fulfil the following criteria:

1) clinical evidence of a lesion of the ulnar nerve at the elbow;

2) demonstrable slowing of conduction of the ulnar nerve at the elbow;

3) persistent symptoms for at least three months;

4) no rheumatoid disease at the elbow; and

5) no valgus deformity, defined as a carrying angle of more than $5^{\circ}$ greater than the opposite elbow.

All patients had a detailed neurological assessment (DJ) and nerve-conduction studies (NJS) before operation and at 12 months. They were randomly allocated to one of the two operations by the use of sealed envelopes which were only opened in the operating theratre just before the procedure. All surgery was performed by one of two surgeons (NJB or $\mathrm{CJH}$ ), so that both procedures were performed by both surgeons, thus avoiding any technical bias.

Neurological assessments, made before operation and at follow-up, included muscle strength rated on a scale of 0 to 5 , muscle atrophy and sensation evaluated by light touch and static two-point discrimination. Pain in the hand was scored from 5 for severe nocturnal pain to zero. Follow-up review was at two weeks (revascularisation), three months (remyelinisation) and at 12 months (axonal regeneration). Neurological assessments were blinded as regards the operation and made without exposing the elbow.

Additional review of elbow function was by one of the authors not involved in the clinical care (GGG), who recorded the following parameters: pain on a scale of 0 to 5 , complaints of stiffness or instability, the range of move- 
Table I. Elbow assessment after operation in the two groups

\begin{tabular}{llll}
\hline & $\begin{array}{l}\text { Medial } \\
\text { epicondylectomy } \\
(\mathbf{n}=\mathbf{2 5})\end{array}$ & $\begin{array}{l}\text { Anterior } \\
\text { transposition } \\
(\mathbf{n}=\mathbf{2 2})\end{array}$ & $\begin{array}{l}\mathbf{p} \text { value } \\
\text { of difference }\end{array}$ \\
\hline $\begin{array}{l}\text { Range of movement (degrees) } \\
\text { Instability }\end{array}$ & 5 to 122 & 3 to 125 & 0.960 \\
$\begin{array}{l}\text { Grip strength } \\
\text { (mean } \pm \text { SD) }\end{array}$ & None & None & \\
Tenderness & $18.5 \pm 9.19$ & $22.6 \pm 8.26$ & 0.259 \\
\hline
\end{tabular}

Table II. Hand assessment and patient satisfaction after operation in the two groups

\begin{tabular}{|c|c|c|c|c|c|}
\hline & $\begin{array}{l}\text { Medial } \\
\text { epicondylect }\end{array}$ & ny $(n=25)$ & $\begin{array}{l}\text { Anterior } \\
\text { transpositio }\end{array}$ & $(n=22)$ & p value \\
\hline & Preop & Postop & Preop & Postop & of difference \\
\hline $\begin{array}{l}\text { Motor nerve conduction } \\
\text { (mean } \pm \mathrm{SD})\end{array}$ & $26.3 \pm 6.23$ & $32.6 \pm 7.55$ & $30.5 \pm 7.68$ & $34.0 \pm 8.01$ & 0.772 \\
\hline $\begin{array}{l}\text { Muscle atrophy } \\
\text { None } \\
\text { Moderate } \\
\text { Severe }\end{array}$ & $\begin{array}{r}6 \\
10 \\
9\end{array}$ & $\begin{array}{r}13 \\
9 \\
3\end{array}$ & $\begin{array}{r}5 \\
5 \\
12\end{array}$ & $\begin{array}{r}11 \\
5 \\
6\end{array}$ & 0.187 \\
\hline Paraesthesiae & 25 & 10 & 22 & 10 & 0.810 \\
\hline $\begin{array}{l}\text { Two-point discrimination } \\
\text { (mean } \pm \mathrm{SD} \text { ) }\end{array}$ & $10.1 \pm 3.0$ & $6.8 \pm 2.8$ & $10.7 \pm 3.1$ & $9.2 \pm 3.3$ & 0.711 \\
\hline $\begin{array}{c}\text { Muscle power (MRC gra } \\
\text { Grade } \\
1 \\
2 \\
3 \\
4 \\
5\end{array}$ & $\begin{array}{l}7 \\
6 \\
4 \\
2 \\
6\end{array}$ & $\begin{array}{r}1 \\
0 \\
7 \\
5 \\
13\end{array}$ & $\begin{array}{l}8 \\
4 \\
2 \\
1 \\
7\end{array}$ & $\begin{array}{r}3 \\
3 \\
3 \\
1 \\
12\end{array}$ & 0.119 \\
\hline $\begin{array}{l}\text { Pain in the hand } \\
\text { (mean pain score } \pm \mathrm{SD} \text { ) }\end{array}$ & & $0 \pm 0$ & & $0.45 \pm 0.86$ & 0.029 \\
\hline $\begin{array}{l}\text { Patient's opinion } \\
\text { Cured } \\
\text { Better } \\
\text { Same } \\
\text { Worse }\end{array}$ & $\begin{array}{r}12 \\
8 \\
4 \\
1\end{array}$ & $\begin{array}{l}6 \\
6 \\
5 \\
5\end{array}$ & & & 0.027 \\
\hline $\begin{array}{l}\text { Would patient have } \\
\text { operation again? }\end{array}$ & & $\begin{array}{l}\text { Yes: } 23 \\
\text { No: } 2\end{array}$ & & $\begin{array}{l}\text { Yes: } 15 \\
\text { No: } 7\end{array}$ & 0.039 \\
\hline
\end{tabular}

ment, tenderness and grip strength. The last was measured by a mechanical spring-loaded device with a simple analogue scale. The patient was then asked for an opinion on the success of the operation and whether he or she would have the procedure again in the same circumstances.

Operations. Medial epicondylectomy was performed as described by King and Morgan (1959), and transposition of the ulnar nerve as described by Crawford Adams (1985).

\section{RESULTS}

The mean follow-up was 4.5 years with a minimum of one year. None of the patients complained of spontaneous pain in the elbow; some had tenderness at the operation site, but this was not a complaint volunteered by any of the patients and the finding was made on specific examination (Table I).

Few of the outcome variables for hand assessment showed any significant differences (Table II). Pain in the hand was statistically more common after nerve transposition, but was never more than mild. Patient satisfaction and willingness to undergo the same operation again were significantly different. After medial epicondylectomy, considerably fewer patients reported that they were no better or worse after the operation. Nearly all those who had this procedure would have been willing to have the operation again; this applied only to just over half of those who had anterior transposition. This difference in preference applied to the patients of both surgeons.

\section{DISCUSSION}

We have found no other prospective study comparing these two methods of treatment (Dellon 1989; Lundborg 1992), and this is the first study which assessed the elbow postoperatively. This is important since removal of the medial epicondyle may weaken the flexor muscles which arise from it, and perhaps also lead to instability of the joint. 
It is important to cover the bone after medial epicondylectomy to prevent the nerve adhering to it and this is easily done by preserving and then closing the periosteum. Anterior transposition may also lead to nerve tethering and there is current interest in the importance of restriction of the normal gliding of the nerve.

We found few complications at the elbow after either operation. In particular, there was no evidence of medial ligamentous instability after removal of the medial epicondyle, and very few such patients had any pain or tenderness. A number of the neurological variables which we studied favoured medial epicondylectomy, but in our series these differences were not statistically significant.

Three variables did show definite differences: after transposition significantly more patients complained of mild pain in the hand; after epicondylectomy, significantly more patients were satisfied and would have had the operation again.

It is uncertain why medial epicondylectomy is more satisfactory, but one criticism of transposition is that it devascularises more of the nerve. Ogata, Manske and Lesker (1985) have shown that it is associated with a significant decrease in the extrinsic arterial supply, especially just distal to the groove for at least three days. Given that we found no statistically significant differences for motor power or nerve-conduction rates, it may be that sensory fibres are more vulnerable to devascularisation and are more dependent on trophic factors transported along the axon from the periphery. The place of simple decompression is also uncertain; we are now comparing this with medial epicondylectomy.

No benefits in any form have been received or will be received from a commercial party related directly or indirectly to the subject of this article.

\section{REFERENCES}

Adams JC. Anterior transposition of ulnar nerve. In: Standard orthopaedic operations. Third edition. Edinburgh, Churchill Livingstone: 1985:178-9.

Adelaar RS, Foster WC, McDowell C. The treatment of the cubital tunnel syndrome. J Hand Surg [Am] 1984;9:90-5.

Craven PR, Green DP. Cubital tunnel syndrome: treatment by medial epicondylectomy. J Bone Joint Surg [Am] 1980;62-A:986-9.

Dellon AL. Review of treatment results for ulnar nerve entrapment at the elbow. J Hand Surg 1989;14-A:688-700.

Froimson AI, Zahwari F. Treatment of compression neuropathy of the ulnar nerve at the elbow by epicondylectomy and neurolysis. $J$ Hand Surg Am 1980;5:391-5.

King T, Morgan FP. Late results of removing the medial humeral epicondyle for traumatic ulnar neuritis. J Bone Joint Surg $[\mathrm{Br}]$ 1959;41-B:51-5.

Lundborg G. Surgical treatment for ulnar nerve entrapment at the elbow (Editorial). J Hand Surg Br 1992;17:245-7.

Macnicol MF. The results of operation for ulnar neuritis. $J$ Bone Joint Surg [Br] 1979;61-B:159-64.

Ogata K, Manske PR, Lesker PA. The effect of surgical dissection on regional blood flow to the ulnar nerve in the cubital tunnel. Clin Orthop 1985;193:195-8.

Robinson D, Aghasi MK, Halperin N. Medial epicondylectomy in cubital tunnel syndrome: an electrodiagnostic study. J Hand Surg Br 1992; 17:255-6. 